ESTUDIO DE LA BIOLOGIA DEL ISOPODO PARASITO

Cymothoa exigua SCHIOEDTE Y MEINERT, 1884 Y SU

RELACION CON EL HUACHINANGO Lutjanus peru (PISCES:

LUTJANIDAE) NICHOLS Y MURPHY, 1922, A PARTIR DE CAPTURAS

COMERCIALES EN MICHOACAN

\title{
STUDIES ON THE BIOLOGY OF THE PARASITIC ISOPOD \\ Cymothoa exigua SCHIOEDTE AND MEINERT, 1884 AND ITS \\ RELATIONSHIP WITH THE SNAPPER Lutjanus peru (PISCES: \\ LUTJANIDAE) NICHOLS AND MURPHY, 1922, \\ FROM COMMERCIAL CATCH IN MICHOACAN
}

\author{
A. Ruiz L. 1 \\ J. Madrid V. 2 \\ 1 Instituto de Ciencias del Mar y Limnología, Estación Mazatlán \\ Universidad Nacional Autónoma de México \\ Apartado Postal 811 \\ Mazatlán 82240, Sinaloa, México \\ 2 Departamento de Biología \\ Facultad de Ciencias \\ Universidad Nacional Autónoma de México \\ 04510 México, D.F.
}

Recibido en marzo de 1991; aceptado en junio de 1991

\section{RESUMEN}

Se analizaron siete muestras mensuales (enero a diciembre de 1984) del huachinango Lutjanus peru, obtenidas de las capturas comerciales de Michoacán con el objeto de localizar isópodos parásitos. Se obtuvo un total de 236 adultos de Cymothoa exigua en 165 de los 691 peces examinados. Se describe parcialmente el ciclo de vida del isópodo, con anotaciones correspondientes al índice corporal, indice de feminidad, fecundidad relativa, desarrollo embrionario y mortalidad dentro del marsupio. Para evaluar el efecto de la relación hospedero-parásito se estimaron diversos índices de ocurrencia del parásito y se compararon valores del factor de condición $(K)$ por sexos y grupos de talla. No se encontraron diferencias significativas en los valores de $K$ pero se observó una reducción en los valores de los índices de ocurrencia con relación al crecimiento de los peces. La presencia del isópodo en $L$. pens no parece causar daños importantes al hospedero, aunque probablemente incrementa la tasa de mortalidad natural, especialmente en los primeros años de vida.

\section{ABSTRACT}

From commercial catch of the Michoacan fishery, samples of the snapper Lutjanus peru were examined monthly (January to December 1984) for isopod parasites. A total of 236 adult individuals of Cymothoa exigua were found in 165 of the 691 snappers collected. The isopod's life cycle is described partially, with notes about the body index, femininity index, as well as the relative fecundity, marsupial development and pre-hatch mortality. Several indices of parasite 
occurrence and the values of the condition factor $(K)$ in Lutjanus peru, by sexes and size groups, were estimated to evaluate the effect of the host-parasite relationship. No significant differences were found in the $K$ values, but a decreasing of the values of the occurrence indices for $C$. exigua was observed in relation to the fish growth. The presence of isopods in $L$. peru appears slightly harmful to the host, but probably increases the natural mortality rate, especially in the first years of life.

\section{INTRODUCCION}

La costa central del Pacífico mexicano (sur de Sinaloa al sur del estado de Guerrero) cuenta con un gran potencial para la pesca; sin embargo, el acceso a estos recursos se ve limitado debido a la accidentada topografía y a lo estrecho de su plataforma continental. Pese a ello, en esta región se encuentran numerosas pesquerías ribereñas cuyo impacto en la economía es significativo. Para Michoacán, la pesquería de mayor importancia es aquella que está basada en la captura de diversas especies de la Familia Lutjanidae (Ruiz, 1983; Madrid, 1990).

En noviembre de 1983, durante la realización de un estudio preliminar tendiente a evaluar el tamaño de la población de pargos y huachinangos, se observó regularmente la presencia de Cymothoa exigua en una de las cinco especies de Lutjanus que se capturan en la región (Anónimo, 1985).

De igual manera que la mayoría de los miembros de la Familia Cymothoidae, $C$. exigua está considerado como un parásito de peces (Holdich, 1968; Brusca, 1978a, b, 1981), existiendo diversos estudios sobre los efectos en sus hospederos (Keys, 1928; Westman y Nigrelli, 1955; Lewis y Hettler, 1968; Romestand y Trilles, 1979). Son escasos los trabajos en relación al efecto que los cimotoideos tienen sobre las pesquerías de especies comerciales(Weinstein y Heck, 1977; Brusca y Gilligan, 1983), por lo que con esta finalidad se inició un programa de muestreo dirigido a evaluar el daño que este isópodo causa sobre las pesquerías.

Brusca (1981) y Brusca y Gilligan (1983) han reportado a $C$. exigua como parásito de ocho especies de peces, incluyendo a $L$. peru, L. guttatus (ambas especies son capturadas en la región) y $L$. maculatus, aunque la identificación de esta última especie debe ser errónea debido a que $L$. maculatus no aparece reportado en la literatura especializada en la Familia Lutjanidae (Allen, 1985; Allen y Talbot, 1985; Polovina y Ralston, 1987).

\section{INTRODUCTION}

The central Pacific coast of Mexico, from southern Sinaloa to southern Guerrero, presents a great potential for fishing; accessibility to resource, however, is limited because of the rough topography and narrowness of the coastal shelf. Despite this, many small-scale fisheries of significant value to the economy are found in the region. In the case of Michoacan, the most important fishery is based on snappers of the Family Lutjanidae (Ruiz, 1983; Madrid, 1990).

In November 1983, during preliminary studies aimed at the evaluation of the snapper-complex stock, the regular presence of the parasitic isopod Cymothoa exigua was observed in one of the five species of Lutjanus caught in the area (Anónimo, 1985).

Like most of the members of the Family Cymothoidae, $C$. exigua is recognized as a fish parasite (Holdich, 1968; Brusca, 1978a, b, 1981) and there have been many studies of the effects on host health by isopods (Keys, 1928; Westman and Nigrelli, 1955; Lewis and Hettler, 1968; Romestand and Trilles, 1979). However, little information is available about the effect of cymothoids on the fishery of commercial species (Weinstein and Heck, 1977; Brusca and Gilligan, 1983), reason why a sampling program was undertaken to evaluate the damage caused by the parasite to the fishery.

C. exigua has been reported by Brusca (1981) and Brusca and Gilligan (1983) from eight host fish species, including Lutjanus peru, L. guttatus (both species caught in the study area) and $L$. maculatus, but this host identification must be erroneous because $L$. maculatus is not reported in the Family Lutjanidae specialized literature (Allen, 1985; Alien and Talbot, 1985; Polovina and Ralston, 1987).

In the study area, the parasite was found in the mouth and gill chamber of $L$. peru and because of the parasitic habits of this crustacean, the study of the relation between both species was implemented. This paper 
En la zona de estudio, el isópodo fue encontrado dentro de las cavidades bucal y faríngea de $L$. peru, por lo que considerando la conducta parasitaria de este crustáceo se decidió efectuar el estudio de la relación entre ambas especies. Este fue el objetivo central del presente trabajo, aunque se incluyen además algunos aspectos relativos a la biología de $C$. exigua así como del daño causado a la pesquería por esta relación.

\section{MATERIALES Y METODOS}

El estudio se efectuó durante los meses de enero a diciembre de 1984, aunque solamente se consiguieron muestras en siete de los doce meses. Los peces se obtuvieron de la captura comercial efectuada con anzuelo, a lo largo de una extensión de aproximadamente $100 \mathrm{~km}$ en la costa de Michoacán (Fig. 1). Ocasionalmente se acompañó a los pescadores a la zona de captura, aunque la generalidad de los muestreos fueron realizados durante el desembarco, procediéndose inmediatamente a la revisión de los ejemplares en ambos casos.

Se midió la longitud patrón (SL) y peso total (TW) de los peces con precisión mínima de $1.0 \mathrm{~mm}$ y $1.0 \mathrm{~g}$, respectivamente. El sexo y condición gonádica de los peces fueron determinados únicamente cuando esto fue posible (436 casos) debido a que un alto porcentaje de los mismos se eviscera a bordo y los órganos internos son posteriormente arrojados fuera de la embarcación. La edad de los peces fue determinada utilizando el método de lectura de escamas, reportándose los resultados preliminares obtenidos con esta metodología en Ruiz et al. (1985).

Para la evaluación del grado de bienestar del hospedero, en relación a la presencia o ausencia del párasito, se estimó el factor de condición $K$ (Weatherley y Gill, 1987) por sexos y grupos de talla (Weinstein y Heck, 1977).

Se examinaron las cavidades bucal y faríngea de cada uno de los peces de la muestra a fin de detectar la presencia del parásito, efectuar su extracción y registrar el número y posición de los mismos. Los isópodos colectados fueron conservados en formol al $10 \%$. La longitud total (IL) y ancho (IW) de los isópodos fue determinada mediante la utilización de un calibrador vernier, estimándose con una precisión de $0.01 \mathrm{~mm}$. Estas medidas fueron empleadas en la obtención del focuses on that concern, including some aspects related to the biology of $C$. exigua and topics about the fishery damage caused by this relationship.

\section{MATERIALS AND METHODS}

The sampling was done from January to December 1984, but was not always successful and only seven months are represented. Snappers were sampled monthly from commercial hook-and-line fishery off Michoacan, along about $100 \mathrm{~km}$ of coastline (Fig. 1). Occasionally, fish samples were obtained in the fishing area, although most of them were taken from the landings and, in both cases, they were processed immediately after the sampling.

Standard length (SL) of fishes was measured to the nearest $1.0 \mathrm{~mm}$ and total weight (TW) to the nearest $1.0 \mathrm{~g}$. Whenever possible (436 individuals), sex and gonadal condition were recorded. It was not commonly done because fish frequently had been eviscerated and their internal organs thrown overboard. Age determination of fishes was done using the scale reading method and preliminary results of these estimations in L. peru are reported elsewhere (Ruiz et al., 1985).

Condition factor $(K)$ was used to assess the well-being of fish (Weatherley and Gill, 1987), by sexes and size groups, in relation to the presence or absence of isopods (Weinstein and Heck, 1977).

The mouth and gill chamber of each fish were examined to detect the presence of the parasites and to remove them, recording their number and location. The isopods collected were preserved in $10 \%$ formalin. Total lengths (IL) and widths (IW) of isopods were measured to the nearest $0.01 \mathrm{~mm}$ using dial calipers. These measurements were used to estimate the body index (BI $=$ IL/IW). Like most of the cymothoid isopods, $C$. exigua is a protandrous hermaphrodite, and the femininity index (FI; Montalenti, 1941) was used to measure the degree of sex reversal.

Eggs and embryos of the isopod were isolated from the marsupium of females to evaluate relative fecundity (number of eggs per gram of female weight) and to estimate differential mortality at the different marsupial stages, calculated as the quotient of the average number of embryos and pre-hatch mancas with respect to the mean number of eggs. 


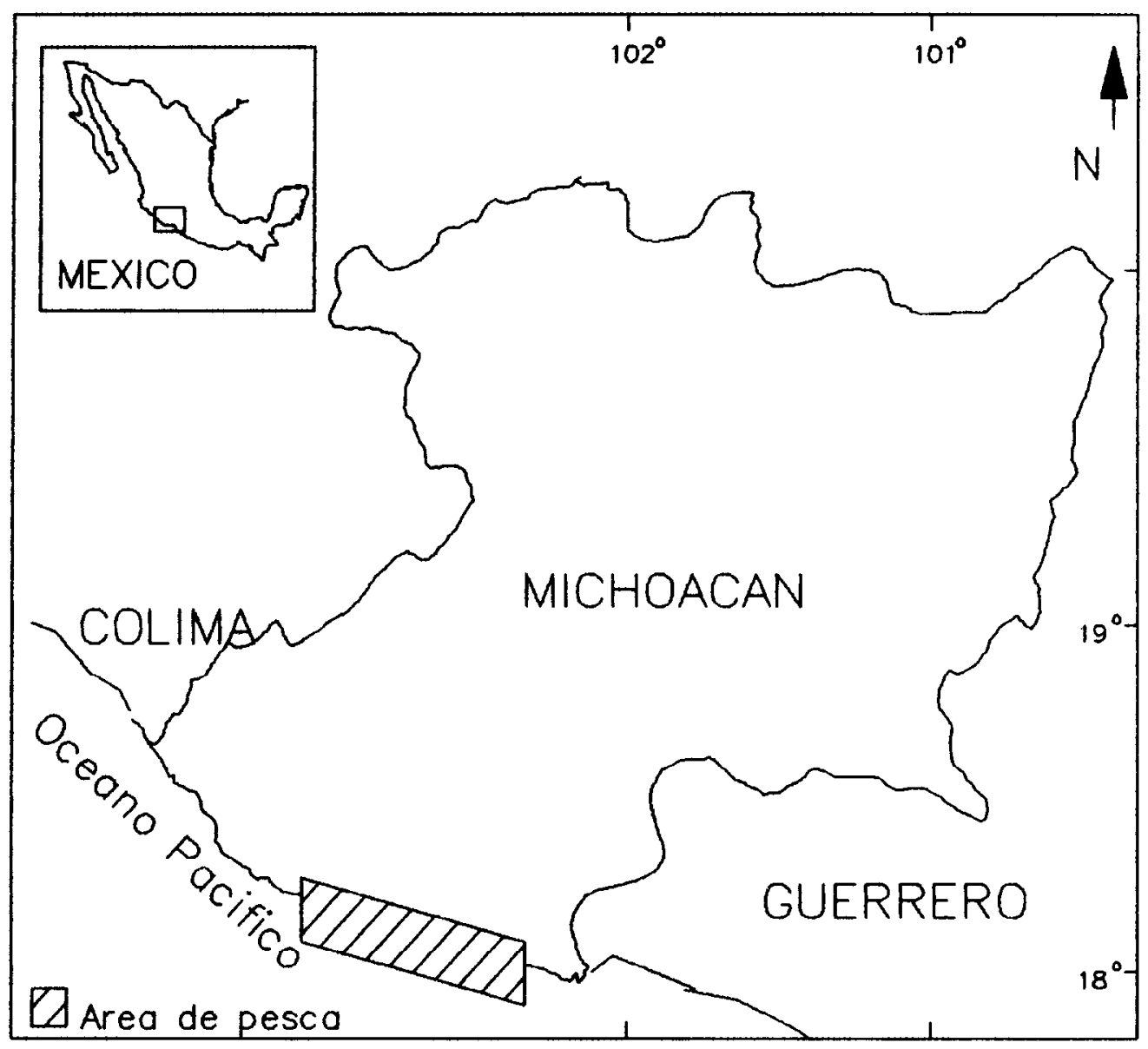

Figura 1. Ubicación del área de estudio.

Figure 1. Location of the study area.

índice corporal $(\mathrm{BI}=\mathrm{IL} / \mathrm{IW})$. Considerando asimismo que $C$. exigua presenta hermafroditismo protándrico, al igual que la mayoría de los isópodos cimotoideos, se evaluó el índice de feminidad (FI; Montalenti, 1941) con el objeto de determinar el grado de reversión sexual.

Los huevos y embriones fueron aislados del marsupio de las hembras del isópodo a fin de evaluar la fecundidad relativa (número de huevos por gramo de hembra) y para estimar la mortalidad diferencial en los diferentes estados embrionarios, calculándose ésta como el cociente entre el número promedio de cualquier fase embrionaria con respecto al número promedio de huevos por hembra.
Finally, some indices commonly used in measuring the parasitic occurrence were also calculated, such as prevalence or percent infestation ( $P=$ parasitized fish/total number of fish), range ( $R=$ minimum and maximum number of parasites per host), intensity ( $I=$ total number of parasites/parasitized fish) and abundance ( $A=$ total number of parasites/total number of fish) (Colton, 1974; Dunn, 1977; Leong and Wong, 1987).

\section{RESULTS}

The annual survey produced a total of 691 individuals of $L$. peru; the minimum 
Finalmente, se calcularon algunos indices de uso común en la evaluación de ocurrencia parasitaria tales como la prevalencia o porcentaje de infestación ( $P=$ número de peces parasitados/número total de peces), intervalo $(\mathrm{R}=$ número mínimo y máximo de parásitos por hospedero), intensidad ( $\mathrm{I}=$ número total de parásitos/número de peces parasitados) y abundancia ( $\mathrm{A}=$ número total de parásitos/número total de peces) (Colton, 1974; Dunn, 1977; Leong y Wong, 1987).

\section{RESULTADOS}

A lo largo del año de muestreo se obtuvo un total de 691 ejemplares de $L$. peru con una muestra mínima obtenida en octubre (34) y la máxima en diciembre (190). Si bien la mayoría de los peces fueron examinados después de que éstos fueron eviscerados en la zona de captura, en muchos casos se encontraron apreciables restos de las gónadas, razón por la cual $63.1 \%$ del total de la muestra pudo ser sexado, aunque su estado de maduración no pudo determinarse de forma objetiva. Las longitudes (LS) de los peces variaron de los 17 a los $54 \mathrm{~cm}$, contándose con cuatro grupos de edad dentro del intervalo de longitudes de los peces infestados. Las longitudes medias de estos grupos se situaron en 18.8, 29.3, 36.6 y $43.2 \mathrm{~cm}$, respectivamente.

Se encontraron isópodos en 165 ejemplares de L. peru ( $52.7 \%$ eviscerados) tanto en la cavidad bucal como en la cavidad faríngea. En total, fueron colectados 236 adultos (machos y hembras) de $C$. exigua. Debe señalarse que si bien un elevado porcentaje de la captura es inmediatamente eviscerado, normalmente no se extrae el aparato branquial puesto que es un medio para la detcrminación del grado de frescura del producto, de forma que esta práctica (evisceración) no incide sobre la presencia del isópodo en la cavidad faríngea.

\section{Biología del parásito}

La totalidad de las hembras del isópodo se localizaron dentro de la cavidad bucal del hospedero sujetas a la lengua. Los machos se presentaron tanto en la cavidad faríngea, en forma aislada, como en la cavidad bucal, unidos a una hembra. Esta última posición sugirió una posible actividad copulatoria, tal number was observed in October (34) and the maximum in December (190). Although most of the fishes were collected after they were eviscerated on board, it was possible to distinguish the sex of $63.1 \%$ in the whole sampled by means of remainder tissues. It was not possible to evaluate the gonadal condition by the same way. Standard length (LS) range for fishes was from 17 to $54 \mathrm{~cm}$, including four age-length groups for the parasitized fish. Average length was $18.8,29.3,36.6$ and $43.2 \mathrm{~cm}$ for each group, respectively.

Isopods were found on 165 individuals of L. peru ( $52.7 \%$ were eviscerated fish), in their mouth and in their gill chamber. A total of 236 adult specimens (males and females) of $C$. exigua were collected. Evisceration of fishes does not include gill arches since they are used to determine the freshness state of fishes and, therefore, this practice does not have a heavy effect on the presence of the isopod in the gill chamber.

\section{Parasite biology}

All female isopods were found within the buccal cavity, attached to the host's tongue. Males were present in the gill chamber as well as in the mouth, in this last situation clinging to a female. This would suggest a copulatory position, as Brusca (1981) has pointed out, but so far there is not enough evidence to confirm it.

Length range for females of $C$. exigua was from 21 to $37 \mathrm{~mm}$ and males from 8 to $19 \mathrm{~mm}$. The mean body index (BI) was 2.11 for females and 2.20 for males. In relation to the femininity index (FI), it was observed that the sex change in $C$. exigua occurs ncar to a value of 45 , above of which more than $80 \%$ of females arc located and which could be reached by males who have more than $10 \mathrm{~mm}$ of length (Fig. 2).

The extent of the size range in males having high FI values could indicate that size is responsible for sex reversal only when no other resident female exists in the host. This could explain the differences in size of ovigerous female isopods which probably have an inhibitory effect on the sex change process of males but not on their growth.

Once the parasite acquires the female condition, the body morphological changes observed during this study suggest five maturity phases preceding the eclosion of manca 


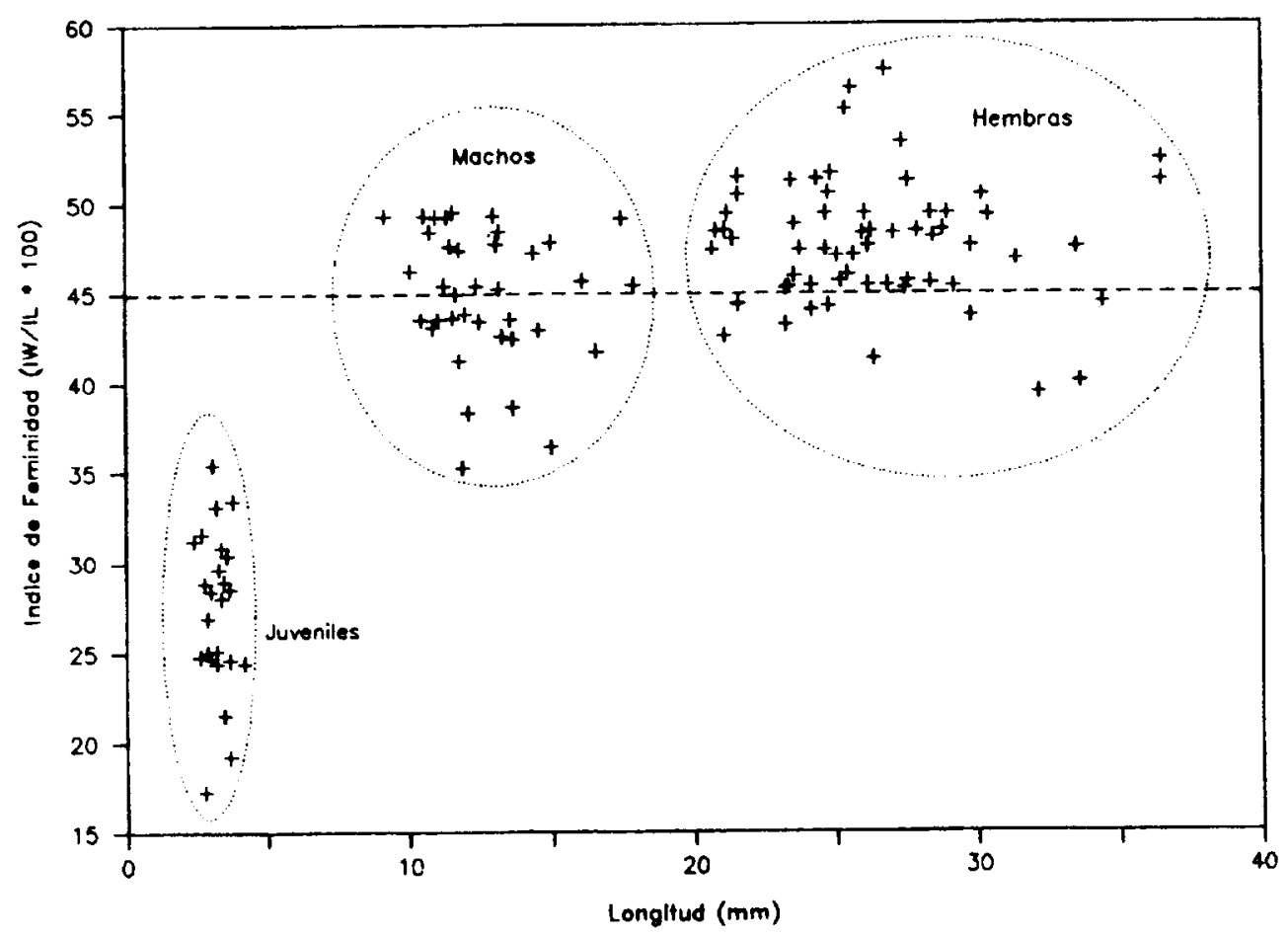

Figura 2. Indice de feminidad en juveniles y adultos, machos y hembras, de Cymothoa exigua.

Figure 2. Feminity index for male and female adults and juveniles of Cymothoa exigua.

como ha sugerido Brusca (1981), aunque hasta la fecha no haya sido posible confirmarlo.

El intervalo de longitud (IL) observado para las hembras de $C$. exigua tuvo una variación de 21 a $37 \mathrm{~mm}$, mientras que el de los machos se situó entre 8 y $19 \mathrm{~mm}$. El índice corporal (BI) obtenido fue de 2.11 para las hembras y de 2.20 para machos. En relación al indice de feminidad (FI), pudo observarse que la reversión sexual en el isópodo ocurre cuando se alcanza un valor cercano a 45 , a partir del cual se ubicó más del $80 \%$ de las hembras y que se presentó cuando los machos alcanzaron tallas superiores a los $10 \mathrm{~mm}$ (Fig. 2).

La amplitud del intervalo de longitud en el que se ubicaron machos con elevados valores del FI podría indicar que el tamaño adquirido sería responsable del cambio de sexo solamente en el caso de que dentro del hospedero no existiera previamente otra hembra. Esto podría explicar las diferencias de tamaño en las hembras ovígeras del isópodo, las cuales pro- stage juveniles. These phases of external changes are the following: (1) oostegites absent; (2) oostegites rudimentary; (3) oostegites fully developed; (4) macroscopical development of fertilized eggs; (5) post-brood body cavity empty and occasionally with advanced signs of body decomposition. In the fourth phase, three basic embryological stages were observed: (a) cleavage stage, (b) segmented larva and (c) pre-hatch manca.

Besides morphological changes in females, the relative fecundity for $C$. exigua (ranging from 0.8 to $1.2 \mathrm{~g}$ in weight) was estimated. A range from 480 to 720 eggs per female was observed, with a mean of 600 eggs per gram of female weight. The mortality values estimated for each marsupial stage was as follows: (a) egg to embryo, 24.5\%; (b) embryo to pre-hatch manca, $15.0 \%$; (c) overall marsupial mortality, $36.0 \%$.

In several cases (17), females of different sizes with empty body cavities (a sign of 
bablemente tengan algún efecto inhibitorio sobre el proceso de reversión sexual pero no sobre el crecimiento del macho.

De acuerdo a lo observado en el presente trabajo, una vez que el parásito adquiere la condición femenina, se producen cambios morfológicos que pueden sugerir distintas etapas de maduración previas a la liberación de las mancas o juveniles. Estas fases de transformación son las siguientes: (1) oosteguitos ausentes; (2) oosteguitos rudimentarios; (3) oosteguitos totalmente desarrollados; (4) desarrollo macroscópico de los huevos fecundados; (5) la cavidad corporal se presenta vacía después de la liberación de las mancas y en ocasiones muestra signos de descomposición corporal. Para la cuarta fase de las arriba señaladas, pudieron observarse tres estadios de desarrollo embriológico: (a) etapa de segmentación, (b) embriones segmentados y (c) mancas en fase previa a su liberación.

Aunado a los cambios morfológicos, se hizo una estimación de la fecundidad relativa en hembras de $C$. exigua cuyo peso varió de 0.8 a $1.2 \mathrm{~g}$. Se obtuvo un intervalo de 480 a 720 huevos por hembra, con una media de 600 huevos por unidad de peso $(\mathrm{g})$ de la hembra. Los valores de mortalidad evaluados para cada fase del desarrollo embrionario fueron los siguientes: de huevo a embrión, $24.5 \%$; de embrión a manca, $15.0 \%$; mortalidad marsupial total, $36.0 \%$.

Se registraron diversos casos (17) de hembras de diferente tamaño que presentaban la cavidad corporal totalmente vacía luego de la liberación de las mancas, mostrando los órganos internos severamente comprimidos y en algunos casos con signos evidentes de descomposición en la cutícula externa y en los tejidos internos.

Con relación a los hábitos reproductivos de muchos cimotoideos, se ha discutido sobre la ocurrencia de un desove único seguido por la muerte de la hembra aunque, considerando la variación en longitud de las hembras, no se ha rechazado del todo la posibilidad de cópulas y desoves múltiples, con la subsiguiente regeneración de tejidos después de cada desove (Holdich, 1968; Brusca, 1978, 1981). En este trabajo, la descomposición en el cuerpo de hembras desovadas sugiere la existencia de un solo desove seguido de la muerte de la hembra, siendo probable que la diferencia de tallas sea una consecuencia del tamaño adquirido por los machos antes del cambio de sexo y por el recent brood) were found, showing the internal organs severely compressed and some of them presented evident signs of decomposition in the external cuticle and in the inner tissues.

Refering to the reproductive behavior of many cymothoids, previous authors have argued in favor of a single brood followed by death of the females, but taking into consideration the great variation of size in females, the possibility of multiple copulations or broods, including regeneration of tissues after each brood, has not been entirely rejected (Holdich, 1968; Brusca, 1978, 1981). Here, the presence of post-brood body deterioration suggested that a single brood occurs, with the difference of size in those females due to the length acquired by males before the sex change, and successive growth of females during the pre-copulatory interval.

\section{Host infestation}

Most of the infested fish showed a large proportion of the parasites dwelling in their buccal cavity, mainly single ovigerous females (43.03\% of the parasitized fish) and a small proportion $(24.84 \%$ ) with isopod couples (i.e. males clinging to females). Single males of the isopod were always found in the gill chamber, in one of the two sides of the head $(15.15 \%)$ or occupying both sides simultaneously (4.24\%). Finally, a small proportion $(11.52 \%)$ of the infested fish had isopods in the mouth (females) and the gill chamber (males) at the same time (Table 1).

Multiple infestations, defined by Brusca (1981) as the co-occurrence of two males or two females, were found in the present work. and besides the $4.24 \%$ of paired males in the gill chamber, a small proportion of about $1.2 \%$ of the infested fishes had three parasites per host, considered an anomalous condition. One of the two recorded cases of triple infestation was observed to occur in the mouth, but probably the cause of a third isopod was the escape from the gill chamber after the host was caught.

As a consequence of the high proportion of fish infested by two or three isopods the value of the intensity index was higher than 1.0 throughout the year, remaining practically constant. With respect to the other indices evaluated, seasonal fluctuations of abundance and prevalence values were observed with a 
crecimiento de la hembra previo a la fecundación.

\section{Infestación en el hospedero}

Una elevada proporción de los isópodos se encontró en la cavidad bucal de los peces parasitados, principalmente hembras ovígeras (43.03\% de los peces parasitados) y una menor proporción (24.84\%) de isópodos pareados (hembra y macho). En forma aislada, los machos siempre se encontraron localizados en la cavidad faríngea, en cualquiera de los lados de la cabeza (15.15\%) o bien ocupando ambos lados $(4.24 \%)$. Finalmente, una reducida proporción de los isópodos fue encontrada ocupando simultáneamente la cavidad bucal (hembra) y la cavidad faríngea (macho) (Tabla 1).

Las infestaciones múltiples, definidas por Brusca (1981) como la ocurrencia simultánea de dos hembras o dos machos, fueron observadas durante el transcurso del presente trabajo y además del $4.24 \%$ de peces infestados por dos machos en ambos lados de la cabeza, se registró una pequeña proporción de aproximadamente $1.2 \%$ de peces parasitados por tres isópodos, considerándose como condición anómala. Uno de los dos registros ocurrió dentro de la cavidad bucal, aunque probablemente la presencia de un tercer isópodo en esta situación se haya debido a un desplazamiento del mismo hacia la cabeza lucgo de que cl pez fuese capturado.

Como consecuencia del elevado nivel de peces infectados por dos o más isópodos el valor del indice de intensidad fue superior a 1.0 a lo largo del año, permaneciendo prácticamente constante. Con respecto al resto de los índices evaluados, se observaron fluctuaciones temporales en la abundancia y la prevalencia, con un lígero desfase de este último con respecto a la abundancia (Fig. 3).

Los máximos valores de abundancia y prevalencia se presentaron durante la estación para la que se ha reportado el máximo de reclutamiento de L. peru (Madrid, 1990). Esta coincidencia podria indicar que la infestación se da tempranamente dentro del ciclo de vida de los peces, cuando éstos inician su fase demersal.

Por lo que respecta a la estructura poblacional del hospedero, fue posible establecer un análisis comparativo de la ocu- slight delay of prevalence in relation to abundance (Fig. 3).

The highest values of abundance and prevalence occurred during the seasons reported as time of major recruitment for $L$. peru (Madrid, 1990). This coincidence could indicate that fishes are infested early, when they leave their planktonic stage to start the demersal phase of their life cycle.

With respect to the population structure of the host, data allowed to establish a comparison of isopod occurrence between different sex and size groups. No significant differences between sexes were found $(t$-test; $P<0.05)$, but the fact that a large number of eviscerated unsexed fishes were included in this survey, sometimes greater than $30 \%$ of the sample (Table 2), would be enough to invalidate the results obtained.

In relation to the age-length structure of the fish population, a higher occurrence of $C$. exigua was observed in the smallest (younger) groups of $L$. peru (Table 3 ), with decreasing incidence related to fish growth $(r=-0.88)$. This reinforces the idea that infestation begins in juveniles of $L$. peru, probably in shallow waters where they seek food and protection.

Effect of parasite infestation on the host population

To estimate the degree of damage caused by $C$. exigua to the host population, the condition factor $(K)$ was compared for both sexes and four length-groups. At first, sex does not appear as an important factor since there were no significant differences when $K$ values from both sexes of parasitized fish were compared, neither when the comparison among condition coefficient values of population, males and females, for both healthy and parasitized fishes, was done. When only parasitized specimens were taken into account, higher values of $K$ were occasionally found than when considering the whole sample (Table 4).

On the other hand, it seems that $K$ decreases as the age or length increases, but in relation to parasite presence, fishes from the same length group do not show significant differences, except in April 1984, when only two of 62 individuals were parasitized (Table 5). 
Ruiz L. y Madrid V.: Estudio de la biología del isópodo parásito Cymothoa exigua

Tabla 1. Datos de los muestreos mensuales de Lutjanus peru y Cymothoa exigua. (a) Tamaño de muestra; (b) peces parasitados; (c) número de parásitos; ( $\mathrm{PM}$ ) parásitos en la cavidad bucal; ( $\mathrm{PG}$ ) parásitos en branquias; (PB) parásitos en ambas posiciones; (P) prevalencia; ( $R$ ) rango; (I) intensidad; (A) abundancia. Enero a diciembre de 1984.

Table 1. Monthly sampling data for Lutjanus peru and Cymothoa exigua. (a) Sample size; (b) parasitized fishes; (c) total number of parasites; (PM) parasites in mouth; (PG) parasites in gill cavity; (PB) parasites in both sitcs; (P) prevalence; (R) range; (I) intensity; (A) abundance. January to December 1984 .

\begin{tabular}{|c|c|c|c|c|c|c|c|c|c|c|}
\hline Mes & $\mathrm{a}$ & $b$ & c & $\mathrm{PM}^{*}$ & $\mathrm{PG}^{*}$ & $\mathrm{~PB}^{*}$ & $P$ & $\mathrm{R}$ & I & A \\
\hline Encro & 119 & 34 & 42 & $\begin{array}{r}25 \mathrm{~s} \\
7 \mathrm{~d}\end{array}$ & $1 \mathrm{~s}$ & $1 d$ & 28.6 & $1-2$ & 1.2 & 0.35 \\
\hline Marzo & 40 & 13 & 21 & $\begin{array}{l}3 \mathrm{~s} \\
6 \mathrm{~d}\end{array}$ & $2 s$ & $2 d$ & 32.5 & $1-2$ & 1.6 & 0.53 \\
\hline Abril & 62 & 2 & 3 & $\begin{array}{l}1 \mathrm{~s} \\
1 \mathrm{~d}\end{array}$ & & & 3.2 & 1.2 & 1.5 & 0.05 \\
\hline Junio & 91 & 34 & 43 & $\begin{array}{r}12 \mathrm{~s} \\
1 \mathrm{~d}\end{array}$ & $\begin{array}{r}14 \mathrm{~s} \\
1 \mathrm{~d}\end{array}$ & $\begin{array}{l}5 d \\
1 t\end{array}$ & 37.4 & $1-3$ & 1.3 & 0.47 \\
\hline Octubre & 34 & 8 & 14 & $\begin{array}{l}2 s \\
6 d\end{array}$ & & & 23.5 & $1-2$ & 1.8 & 0.41 \\
\hline Noviembre & 155 & 30 & 49 & $\begin{array}{c}10 \mathrm{~s} \\
9 \mathrm{~d} \\
1 \mathrm{t}\end{array}$ & $\begin{array}{l}2 \mathrm{~s} \\
1 \mathrm{~d}\end{array}$ & $7 d$ & 19.3 & $1-3$ & 1.6 & 0.31 \\
\hline Diciembre & 190 & 44 & 64 & $\begin{array}{l}18 \mathrm{~s} \\
11 \mathrm{~d}\end{array}$ & $\begin{array}{l}6 \mathrm{~s} \\
5 \mathrm{~d}\end{array}$ & $4 d$ & 23.2 & $1-2$ & 1.5 & 0.31 \\
\hline Total & 691 & 165 & 236 & $\begin{array}{r}71 \mathrm{~s} \\
41 \mathrm{~d} \\
1 \mathrm{t}\end{array}$ & $\begin{array}{r}25 \mathrm{~s} \\
7 \mathrm{~d}\end{array}$ & $\begin{array}{r}19 d \\
11\end{array}$ & 22.9 & $1-3$ & 1.4 & 0.34 \\
\hline
\end{tabular}

* s, d y t se refieren a infestaciones por uno, dos o tres isópodos.

rrencia del iscipodo por sexo y grupos de talla. No se encontraron diferencias significativas cuando los sexos fueron comparados ( $t$-test; $P<0.05)$ : sin embargo, debido a la alta proporción de ejemplares eviscerados incluidos en las muestras, en ocasiones mayor al $30 \%$, estos resultados podrian ser invalidados (Tabla 2).

En relación a la estructura de talla-cdad de la población de peces, la mayor ocurrencia de $C$. exigua se encontró en los grupos de menor talla de L. peru (Tabla 3), con dismi-
Finally, several degrees of deterioration or replacement of the host's tongue by the females of the parasite were observed, but their relation with the well-being of the fishes was not measured.

\section{DISCUSSION}

Infestation of Lutjanus peru by the isopod $C$. exigua was observed throughout the year, although there is a great variation in the 

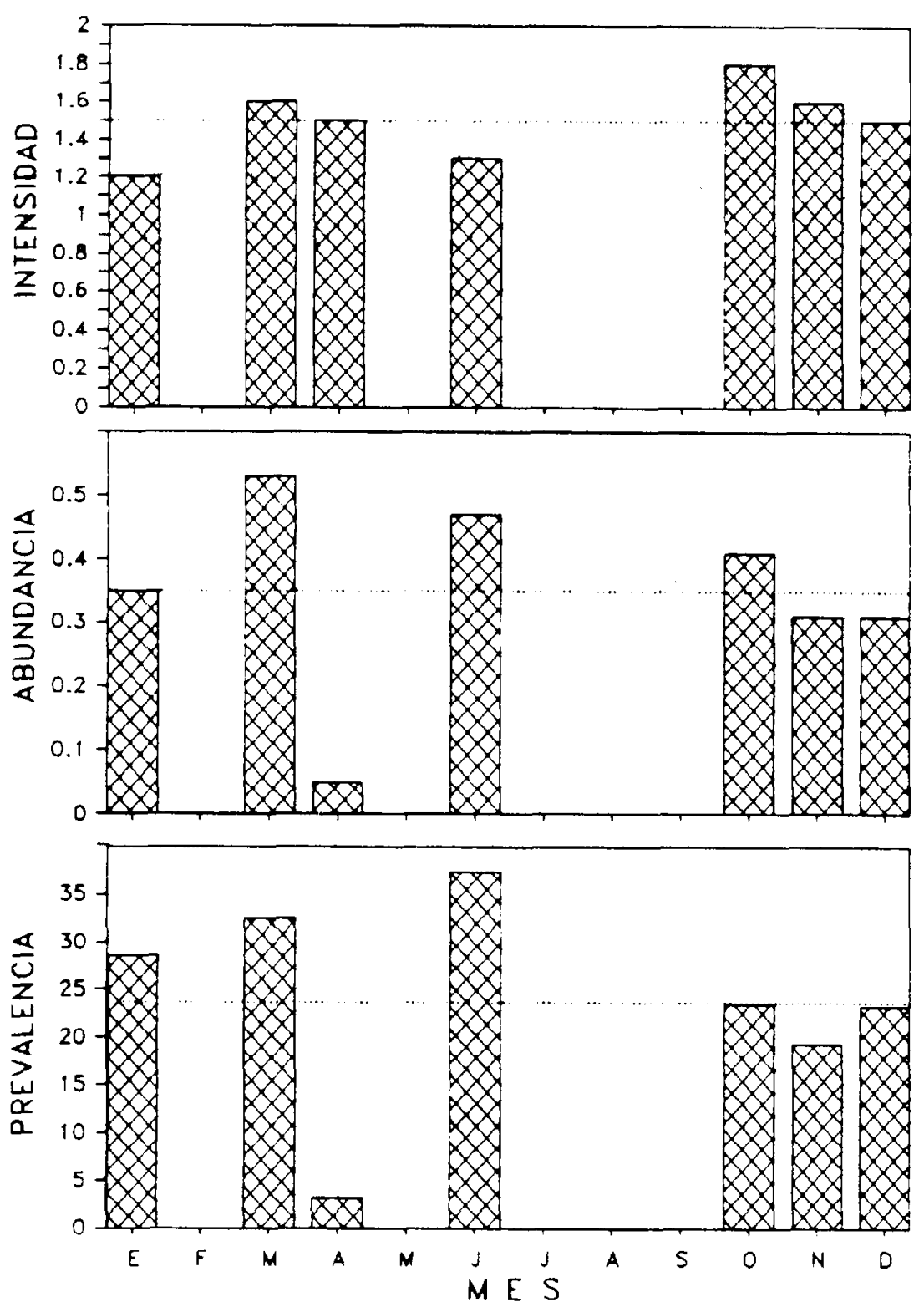

Figura 3. Valores mensuales de los índices de ocurrencia parasitaria de Cymothoa exigua en Lutjanus peru. La línea punteada representa el valor promedio del índice.

Figure 3. Monthly values of the indices of parasitic occurrence of Cymothoa exigua in Lutjanus peru. The dotted line represents the mean value of the indices. 
Ruiz L. y Madrid V.: Estudio de la biología del isópodo parásito Cymothoa exigua

Tabla 2. Proporción de sexos, (m) machos, (h) hembras; (n) número de machos, hembras e individuos de sexo indeterminado de Lutjanus peru; ( $\mathrm{p} \%$ ) frecuencia relativa por sexos de peces parasitados.

Table 2. Sex ratio, $(m)$ males, (h) females; (n) number of males, females and unsexed individuals of Lutjanus peru; ( $\mathrm{p} \%$ ) relative frequency of parasitized fish by sex.

\begin{tabular}{|c|c|c|c|c|c|c|c|}
\hline \multirow[t]{2}{*}{ Mes } & \multirow{2}{*}{$\frac{\text { Proporción sexual }}{\mathrm{m}: \mathrm{h}}$} & \multicolumn{2}{|c|}{ Machos } & \multicolumn{2}{|c|}{ Hembras } & \multicolumn{2}{|c|}{ Indeterminados } \\
\hline & & $\mathbf{n}$ & $\mathrm{p} \%$ & $\mathrm{n}$ & $\mathrm{p} \%$ & $\mathrm{n}$ & $\mathrm{p} \%$ \\
\hline Enero & $1.4: 1.0$ & 31 & 13.0 & 22 & 31.8 & 66 & 34.8 \\
\hline Marzo & $1.3: 1.0$ & 20 & 30.0 & 16 & 25.0 & 4 & 75.0 \\
\hline Abril & $0.7: 1.0$ & 21 & 4.8 & 32 & 3.0 & 9 & 0.0 \\
\hline Junio & $2.7: 1.0$ & 16 & 25.0 & 6 & 50.0 & 69 & 40.6 \\
\hline Octubre & $0.6: 1.0$ & 5 & 40.0 & 9 & 11.1 & 20 & 25.0 \\
\hline Noviembre & $1.1: 1.0$ & 56 & 5.3 & 52 & 9.6 & 47 & 46.8 \\
\hline Diciembre & $0.7: 1.0$ & 64 & 18.7 & 86 & 29.1 & 40 & 10.0 \\
\hline
\end{tabular}

Tabla 3. Presencia de Cymothoa exigua en cuatro grupos de edad del huachinango Lutjanus peru en las capturas comerciales de Michoacán, México. Enero a diciembre de 1984.

Table 3. Presence of Cymothoa exigua in four age-length groups of Lutjanus peru from commercial landings of Michoacan, Mexico. January-December 1984.

\begin{tabular}{lccccc}
\hline Mes & $\begin{array}{c}\text { Tamaño de } \\
\text { muestra }\end{array}$ & \multicolumn{4}{c}{$\begin{array}{c}\text { Talla media (cm) } \\
\text { por grupo de edad }\end{array}$} \\
\cline { 3 - 6 } & & 18.8 & 29.3 & 36.6 & 43.2 \\
\hline Enero & 119 & 4 & 29 & 1 & \\
Marzo & 40 & 7 & 4 & & 2 \\
Abril & 62 & 1 & & 1 & \\
Junio & 91 & 23 & 11 & & \\
Octubre & 34 & 3 & 4 & 1 & \\
Noviembre & 155 & 14 & 13 & 3 & \\
Diciembre & 190 & 26 & 18 & & 2 \\
\hline Total & 691 & 78 & 79 & 6 & \\
\hline
\end{tabular}

nución de la incidencia en relación al crecimiento de los organismos $(r=-0.88)$. Este resultado refuerza la idea de que la infestación se produce en las etapas juveniles de $L$. peru, probablemente en aguas someras utilizadas como zonas de crianza. occurrence rates. This is probably related to fish-stock structure at fishing time.

The life cycle of $C$. exigua shows several similarities with other members of the Family Cymothoidae. The patterns of marsupial development and egg and embryo stages, de- 
Efecto de la infestación en la población del hospedero

Para evaluar el daño causado por el isópodo a la población hospedera, se comparó el valor del factor de condición $K$ en ambos sexos así como en los grupos de longitud. En primera instancia, el sexo no parece ser un factor importante dado que no hubo diferencias significativas cuando los valores de $K$ en ambos sexos fueron confrontados (Tabla 4). Cuando el análisis de los valores de $K$ para machos y hembras se realizó comparando aisladamente peces infestados y sanos, los resultados fueron similares. Ocasionalmente se encontraron valores más altos de $K$ en la fracción parasitada que cuando se consideró el total de la población.

Por otra parte, al efectuarse la comparación entre los valores de $K$ de los distintos grupos de edad se aprecia una disminución en el valor de este índice conforme la talla media se incrementa; sin embargo, entre peces del mismo grupo de tallas tampoco se encontraron diferencias significativas, excepto en abril cuando únicamente dos de los 62 individuos que integraron el total de la muestra estuvieron parasitados (Tabla 5).

Finalmente, se observó que las hembras del isópodo causaron distintos grados de degeneración e incluso reemplazamiento de la lengua del hospedero, sin embargo no fue evaluada la relación de este proceso con el grado de bienestar del hospedero.

\section{DISCUSION}

Se observo infestación de Lutjanus peru por el isópodo Cymothoa exigua durante todo el año aunque hubo gran variación en las tasas de ocurrencia. Esto probablemente está relacionado con la estructura del stock al momento de la captura.

El ciclo biológico de $C$. exigua muestra diversas similitudes con otros miembros de la Familia Cymothoidae. Entre otros, el patrón de desarrollo embrionario descrito aquí para $C$. exigua es consistente con los descritos por Bowman (1960), Brusca (1978a, b) y Sartor y Pires (1988) para otras especies de la familia.

De acuerdo con Brusca (1978b), las hembras del isópodo Lironeca vulgaris tienen en promedio $\mathbf{4 4 0}$ a $\mathbf{5 4 0}$ huevos por individuo, mientras que para $C$. exigua se observ 6 un intervalo de 480 a 720 huevos por gramo de scribed here in $C$. exigua, are consistent with those described by Bowman (1960), Brusca (1978a, b) and Sartor and Pires (1988) for other species of cymothoids.

According to Brusca (1978b), females of the isopod Lironeca vulgaris carry $440-540$ eggs per individual; females of $C$. exigua carried 480-720 eggs with an average of 600 eggs per gram of female weight. Holdich (1968) reports an overall marsupial mortality of $36.4 \%$ for another parasite isopod ( $D y$ namene bidentata), of which $12 \%$ occurred during the last inner marsupial molt. Values of overall mortality obtained here for $C$. exigua are similar to those found by Holdich (1968).

With respect to the protandrous hermaphroditism of $C$. exigua, the great variation in size of ovigerous and post-brooded females of this isopod could suggest that sexual reversal is stimulated by the presence of a second male in the gill chamber or, when it is absent, the change is a natural consequence of the growth of the isopod. According to the results, if a second male was present the sex change in the former isopod could occur probably between 10 and $18 \mathrm{~mm}$ of length, when the FI reaches values near to 45 .

In opposition to what has been reported by Brusca (1981) for $C$. exigua, multiple infestations of this isopod on $L$. peru were recorded, and the proportion of duplicates and triplicates of the parasite was higher to that reported by Weinstein and Heck (1977), although triplicates seem to be very unusual because of their lower occurrence, less than $1.0 \%$ in the whole fish sample. Because of the lower proportion of fishes with triple infestation (2), their length, 22 and $28 \mathrm{~cm}$ respectively, cannot be considered to explain the increase of the incidence level.

Data analyses and reviewed literature allow to propose the hypothesis that $L$. peru is infested early in its life cycle by several isopods at onee with successful implantation of some of these. The life cycle of the isopods could be completed in the host and after a female of $C$. exigua finishes her cycle and dies, it may be replaced by a male breaking this sequence when no other male is available. There are not enough data to confirm that idea, but analysis of percent infestation indicates that values of this index decrease in older length-groups, reason why it is possible to suppose that infestation occurs only during the former stages of the host's life cycle. 
Tabla 4. Comparación de los valores del factor de condición $(K)$ entre la población muestreada y los peces parasitados para grupos de ambos sexos (MS), machos (M) y hembras (H) de Lutjanus peru. Michoacán, México, enero a diciembre de 1984.

Table 4. Comparison between condition factor $(K)$ values of the sampled population and parasitized fish for groups of mixed sexes (MS), males (M) and females (H) of Lutjanus peru. Michoacan, Mexico, January-December 1984.

\begin{tabular}{|c|c|c|c|c|c|c|}
\hline \multirow[t]{3}{*}{ Mes } & \multicolumn{6}{|c|}{ Factor de condición } \\
\hline & \multicolumn{3}{|c|}{ Poblacional } & \multicolumn{3}{|c|}{ Peces parasitados } \\
\hline & MS & $\mathbf{M}$ & $\mathrm{H}$ & MS & $\mathbf{M}$ & $\mathrm{H}$ \\
\hline Enero & 1.26 & 1.21 & 1.23 & 1.26 & 1.23 & 1.21 \\
\hline Marzo & 1.37 & 1.35 & 1.34 & 1.37 & 1.36 & 1.33 \\
\hline Abril & 1.19 & 1.17 & 1.19 & $1.05^{*}$ & $1.02^{*}$ & $1.09^{*}$ \\
\hline Junio & 1.35 & 1.49 & 1.45 & 1.36 & 1.41 & 1.50 \\
\hline Octubre & 1.24 & 1.29 & 1.20 & 1.22 & 1.22 & 1.36 \\
\hline Noviembre & 1.23 & 1.14 & 1.16 & 1.26 & 1.29 & 1.26 \\
\hline Diciembre & 1.26 & 1.26 & 1.26 & 1.26 & 1.27 & 1.26 \\
\hline
\end{tabular}

* Diferencia significativa ( $t$-test, $P<0.05)$.

Tabla 5. Valores promedio del factor de condición $K$ en cuatro grupos de edad de Lutjanus peru para peces sanos y parasitados (p). Michoacán, México, enero a diciembre de 1984.

Table 5. Mean values of the condition factor $K$ for healthy and parasitized fish (p) in four age-length groups of Lutjanus peru. Michoacan, Mexico, January-December 1984.

\begin{tabular}{|c|c|c|c|c|c|c|c|c|c|}
\hline \multirow[t]{3}{*}{ Mes } & \multicolumn{9}{|c|}{ Factor de condición } \\
\hline & \multirow[t]{2}{*}{ Poblacional } & \multicolumn{8}{|c|}{ Grupos de edad } \\
\hline & & 1 & $1 p$ & 2 & $2 p$ & 3 & $3 p$ & 4 & $4 p$ \\
\hline Enero & 1.26 & 1.43 & 1.42 & 1.23 & 1.22 & 1.17 & 1.13 & & \\
\hline Marzo & 1.37 & 1.41 & 1.38 & 1.36 & 1.37 & & & 1.31 & 1.32 \\
\hline Abril & 1.19 & 1.16 & $1.02^{*}$ & & & 1.21 & 1.19 & & \\
\hline Junio & 1.35 & 1.40 & 1.36 & 1.31 & & & & & \\
\hline Octubre & 1.24 & 1.25 & 1.19 & 1.25 & 1.24 & 1.26 & 1.25 & & \\
\hline Noviembre & 1.23 & 1.29 & 1.28 & 1.25 & 1.25 & 1.19 & 1.20 & & \\
\hline Diciembre & 1.26 & 1.28 & 1.28 & 1.25 & 1.24 & & & & \\
\hline
\end{tabular}

* Diferencias significativas $(t$-test, $P<0.05)$

peso de las hembras, con un promedio de 600 huevos por gramo. Holdich (1968) reporta una mortalidad total de $36.4 \%$ para embriones de otro isópodo parásito de peces (Dynamene
With respect to the host-parasite relationship, the isopod appcars harmless or only somewhat harmful. Females of $C$. exigua are capable of destroying or causing atrophy to 
bidentata), de los cuales el $12 \%$ ocurre durante la última moda embrionaria. En este trabajo los valores de mortalidad total son muy similares a los presentados por Holdich (1968).

En relación al hermafroditismo protándrico de $C$. exigua, la enorme variación en el tamaño de hembras ovígeras y desovadas sugiere que la reversión sexual es estimulada por la presencia de un segundo macho en la cavidad faríngea $o$, en caso de que éste no existiera, el cambio podría producirse como una consecuencia natural del crecimiento. De acuerdo con los resultados obtenidos, la reversión sexual en presencia de un segundo macho podría darse entre los 10 y $18 \mathrm{~mm}$ de longitud, cuando el indice de feminidad alcanza valores cercanos a 45.

Al contrario de lo reportado por Brusca (1981) para $C$. exigua, se han registrado infestaciones múltiples en $L$. peru y la proporción de dobles y triples presencias del parásito fue superior a la reportada por Weinstein y Heck (1977), aunque si bien los triplicados parecen ser bastante raros ya que su ocurrencia es inferior al $1.0 \%$ del total de la muestra, presentándose en este caso en dos peces cuyo intervalo de longitud total se situo entre 22 y $28 \mathrm{~cm}$, no pudiendo inferirse si el tamaño fue un factor importante para que se diera este nivel de incidencia del parásito.

El análisis de los datos y la literatura revisada permiten proponer la hipótesis de infestación temprana del huachinango por varios isópodos a la vez, siendo exitosa la implantación de un número reducido de los mismos. Posteriormente, el ciclo de vida del isópodo puede ser completado en el hospedero y luego de que una hembra concluye su ciclo y muere, ésta puede ser reemplazada por un macho, rompiéndose esta secuencia cuando no existe otro macho en el hospedero. No existen evidencias suficientes para dar validez a esta idea; sin embargo, el análisis del porcentaje de infestación indica que los valores de este índice disminuyen con la edad, razón por la cual es posible suponer que la infestación sólo ocurre durante las primeras etapas del ciclo de vida del hospedero.

Con respecto a la relación hospedero-parásito, el isópodo se presenta como benigno o ligeramente dañino. Las hembras de C. exigua son capaces de destruir o causar la atrofia de la lengua del huachinango y eventualmente sustituirla, sin que esto implique the host's tongue and, eventually substitute for it, although there is no evidence to consider the tongue's replacement as a highly evoluted strategy (Brusca and Gilligan, 1983). In the present study, the tongue degeneration of the host was observed on several occasions and if well the relation between the degree of deterioration of the tongue and the well-being of the host was not evaluated, the analyses of condition factor for sexes and length-groups do not show any direct relationship.

Excluding the tissue degeneration caused by the settlement of females of the isopod on the host's tongue, no other evidence of damage has been detected as a result of the host-parasite relationship, except a more intense reddish coloration in the gill arch without visible oradation or collapse of the branchial filaments.

Additional reports about the damage caused by male parasites include hematophagy (Morton, 1974; Brusca, 1981) and excessive mucus secretion on gill chamber surfaces which eventually affect the respiratory process (Smith, 1983). Lanzing and O'Conner (1975) found that infested fish tend to be underweight but only for hosts carrying two or more isopods. In this study, however, the values of the $K$ factor indicate that the presence of isopods of both sexes does not disturb the general well-being of the host; even in some parasitized groups the $K$ values were higher than those of healthy fish groups.

At present, parasitism by $C$. exigua has demonstrated that it cannot be considered as a cause of serious damage to the host or, in agreement with Weinstein and Heck (1977), C. exigua appears to be a benign parasite whose influence could modify the behavior of heavily parasitized fishes affecting their nutritional habits, their reproductive capacity or their escape response toward predators as occurs with other kinds of parasitism (Milinski, 1984; Giles, 1987). However, from the point of view of the fishery of $L$. peru along the coast of Michoacan, the effect can be considered insignificant at the present time.

\section{ACKNOWLEDGEMENTS}

We are very grateful for the review and interesting comments on this paper from $M$. Hendrickx and R. Brusca.

English translation by the authors. 
una estrategia evolutiva altamente desarrollada (Brusca y Gilligan, 1983). En este trabajo el deterioro en la lengua del hospedero fue observado repetidamente y aunque su relación con el grado de bienestar del hospedero no fue evaluada, el análisis del factor de condición por sexos y grupos de edad no reveló ningín tipo de relación directa.

Excluyendo la degeneración causada por la implantación del parásito hembra sobre la lengua, no fue posible observar ninguna otra evidencia de daño como resultado de la relación, a excepción de una coloración rojiza de mayor intensidad en los arcos branquiales, sin que se manifestaran señales de oradación o colapso en los filamentos branquiales.

Otros reportes de daños causados por estos parásitos incluyen a la hematofagia (Morton, 1974; Brusca, 1981) y excesiva secreción mucosa en las paredes de la cavidad faringea, misma que ocasionalmente puede afectar el proceso respiratorio (Smith, 1983). Lanzing y O'Conner (1975) encontraron que los peces infectados tienden a presentar reducción de peso, aunque solamente es evidente en aquellos que se encuentran infestados por dos o más isópodos. Sin embargo, en este trabajo, los valores de $K$ indicaron que la presencia de isópodos de ambos sexos no produce ninguna alteración notable en el hospedero y por el contrario, se observó que en algunos grupos los peces parasitados presentaron un valor de $K$ superior al de peces sanos.

En resumen, se ha comprobado que $\mathrm{cl}$ parasitismo de $C$. exigua no puede ser considerado coino causante de daños serios sobre $L$. peru 0 , en concordancia con Weinstein y Heck (1977), C. sxigua parece ser un parásito benigno cuya influencia podría modificar el comportamiento de peces con una alta frecuencia de parásitos, afectando sus hábitos alimenticios, su capacidad reproduciva o su respuesta para escapar de depredadores, tal como suele ocurrir con relación a otro tipo de parásitos (Milinski, 1984; Giles, 1987), pero desde el punto de vista de la pesquería del huachinango en la costa de Michoacán, el efecto puede considerarse actualmente como insignificante.

\section{AGRADECIMIENTOS}

Los autores desean agradecer a $M$. Hendrickx y a $R$. Brusca por la revisión e interesantes comentarios realizados al manuscrito

\section{LITERATURA CITADA}

Anónimo (1985). Evaluación y diagnosis de la unidad de pesquería del huachinango (Lutjanus peru) y otras. especies del género en el Pacífico mexicano. Fac. Ciencias, UNAM-CONACYT, México.

Allen, G.R. (1985). Snappers of the world. FAO Fish. Synop., 125, Vol. 6.

Allen, G.R. and Talbot, F.H. (1985). Review of the snappers of the genus Lutjanus (Pisces: Lutjanidae) from the Indo-Pacific, with the description of a new species. Indo-Pacific, 11: 1-87.

Bowman, T.E. (1960). Description and notes on the biology of Lironeca puhi, n. sp. (Isopoda: Cymothoidae) parasite of the Hawaiian moray eel, Gymnothorax eurostus (Abbott). Crustaceana, 1: 82-91.

Brusca, R.C. (1978a). Studies on the cymothoid fish symbionts of the eastern Pacific (Isopoda: Cymothoidae). I. Biology of Nerocila califomica. Crustaceana, 34: 141-154.

Brusca, R.C. (1978b). Studies on the cymothoid fish symbionts of the eastern Pacific (Crustacea: Isopoda: Cymothoidae). II. Biology and systematics of Lironeca vulgaris. Occa. Pap. Allan Hancock Found. (N.S.), 2: 1-19.

Brusca, R.C. (1981). A monograph on the Isopoda Cymothoidae (Crustacea) of the eastern Pacific. Zool. J. Linn. Soc., 73: 117-199.

Brusca, R.C. and Gilligan, M.R. (1983). Tongue replacement in a marine fish (Lutjanus guttatus) by a parasitic isopod (Crustacea: Isopoda). Copeia, 3: 813-816.

Colton, T. (1974). Statistics in Medicine. Little, Brown and Co. Boston, $372 \mathrm{pp}$.

Dunn, J.O. (1977). Basic Statistics: A Priner for Biomedical Sciences. J. Wiley \& Sons, New York, $218 \mathrm{pp}$.

Giles, N. (1987). Predation risk and reduced foraging activity in fish: Experiments with parasitized and non-parasitized three-spined stick-lebacks, Gasterosteus aculeatus L. J. Fish Biol., 31: 37-44.

Holdich, D.M. (1968). Reproduction, growth and bionomics of Dynamene bidentata (Crustacea, Isopoda). Bull. Soc. Zool. London, 156: 137-153. 
Keys, A.B. (1928). Ectoparasites and vitality. Am. Nat., 62: 279-282.

Lanzing, W.J.R. and O'Conner, P.F. (1975). Infestation of Luderick (Girella tricuspidata) populations with parasitic isopods. Aust. J. Mar. Fresh. Res., 26: 355-361.

Leong, T.S. and Wong, S.Y. (1987). Parasites of wild and diseased juvenile golden snapper, Lutjanus johni (Bloch), in floating cages in Penang, Malaysia. Asian Fish. Soc., 1: 83-90.

Lewis, R.M. and Hettler, W.F. (1968). Effect of temperature and salinity on the survival of young Allantic menhaden, Brevoontia tymannus. Trans. Am. Fish. Soc., 97: 344-349.

Madrid, V.J. (1990). Ecología de algunas especies de peces de importancia comercial. Tesis de Maestría, Fac. Ciencias, UNAM, México, 180 pp.

Milinski, M. (1984). Parasites determine a predator's optimal feeding strategy. Behav. Ecol. Sociobiol., 15: 35-37.

Montalenti, G. (1941). Studi sull'ermafroditismo dei cimotoidi. I. Emetha audouinii (M. Edw) e Anilocra physodes (L). Pub. Stazio Zool. Napoli, 18: 337-394

Morton, B. (1974). Host specificity and position on the host in Nerocila phaeopleura Bleeker (Isopoda, Cymothoidae). Crustaceana, 26: 143-148.

Polovina, J.J. and Ralston, S. (1987). Tropical Snappers and Groupers. Biology and Fisheries Management. London, Westview Press, 659 pp.

Romestand, M.B. and Trilles, J.P. (1979). Influences des cymothoadiens Meinertia oestroides, Meinertia parallela et Anilocra physoides (crustaces, parasites de poissons) sur la croissance des pois- sons hotes Boops boops et Pagellus erythrinus (Sparides). Z. Parasit., 59: 195-202.

Ruiz, L.A. (1983). Contribución al conocimiento de los peces de importancia comercial en Bahía Bufadero, Michoacán, México. Tesis, Fac. de Ciencias, UNAM, México, $120 \mathrm{pp}$.

Ruiz, L.A., Girón B., E., Madrid, J. y González B., A. (1985). Algunos aspectos en el estudio de la biología del isópodo parásito Cymothoa exigua (Schioedte \& Meinert, 1884) y su relación con el Huachinango del Pacífico Lutjanus penu (Nichols \& Murphy, 1922) en la costa de Michoacán, Méx. Mem. VIII Cong. Nal. Zool, Saltillo, México, pp. 650-662.

Sartor, S.M. and Pires, A.M.A. (1988). The occurrence of Cymothoa liannae, new species of cymothoid isopod from Brazil, with a comparative study of its postmarsupial development. Crustaceana (Leiden), 55: 147-156.

Smith, F.G. (1983). Crustacean parasites of marine fishes. In: W.E. Ribelin and G. Migaki (eds.), The Pathology of Fishes. Univ. of Wisconsin Press, pp. 189-203.

Weatherley, A.H. and Gill, H.S. (1987). The Biology of Fish Growth. Academic Press, New York, 443 pp.

Weinstein, M.P. and Heck, Jr. K.L. (1977). Biology and host-parasite relationships of Cymothoa excisa (Isopoda: Cymothoidae) with three species of snappers (Lutjanidae) on the Caribbean coast of Panama. Fish. Bull., 75: 875-877.

Westman, J.R. and Nigrelli, J.R. (1955). Preliminary studies of menhaden and their mass mortalities in Long Island and New Jersey waters. New York Fish and Game J., 2: 142-153. 